\title{
Mediterranean Subspecies versus Californian Varieties: An Example from Acmispon (Leguminosae, Loteae)
}

\author{
Dmitry D. Sokoloff ${ }^{1, *}$, Zoya V. Akulova-Barlow ${ }^{2}$ and Rafaël Govaerts ${ }^{3}$ \\ 1 Department of Higher Plants, Biological Faculty, Lomonosov Moscow State University, GSP-1 Leninskie Gory, \\ 119234 Moscow, Russia \\ 2 Independent Researcher, El Cerrito, CA 94530, USA; zakulova@gmail.com \\ 3 Royal Botanic Gardens, Kew, Richmond, Surrey TW9 3DS, UK; R.Govaerts@kew.org \\ * Correspondence: sokoloff-v@yandex.ru
}

Citation: Sokoloff, D.D.;

Akulova-Barlow, Z.V.; Govaerts, R.

Mediterranean Subspecies versus

Californian Varieties: An Example

from Acmispon (Leguminosae,

Loteae). Taxonomy 2021, 1, 226-233.

https://doi.org/10.3390/

taxonomy 1030016

Academic Editor: Ana Juan

Received: 13 June 2021

Accepted: 29 July 2021

Published: 3 August 2021

Publisher's Note: MDPI stays neutral with regard to jurisdictional claims in published maps and institutional affiliations.

Copyright: (c) 2021 by the authors. Licensee MDPI, Basel, Switzerland. This article is an open access article distributed under the terms and conditions of the Creative Commons Attribution (CC BY) license (https:/ / creativecommons.org/licenses/by/ $4.0 /)$.

\begin{abstract}
The tribe Loteae of the family Leguminosae has major centers of diversity in the Mediterranean Region and California. It is used here to illustrate different traditions of taxonomic interpretation of infraspecific variation among researchers in different continents. Recent accounts of European and Mediterranean taxa commonly make an emphasis on recognizing subspecies. In contrast, accounts of North American Loteae recognize all infraspecific taxa as varieties. Harmonization of taxonomic concepts across continents is essential for a more accurate representation of data in global biodiversity databases. It is reasonable to use the rank of subspecies for geographically defined infraspecific units with localized zones of intergradation. Such subspecies may be at least partially compatible across continents and taxonomic groups. In the present paper, we discuss taxa traditionally included in or associated with Acmispon glaber (Vogel) Brouillet (=Syrmatium glabrum Vogel) and demonstrate a need for recognizing three species, of which one has three geographically defined subspecies. Required nomenclatural combinations are proposed. It is proposed that subspecies rather than varieties should be recognized in a number of other species of North American Loteae (and other plant groups). Inland subspecies of Acmispon glaber and A. maritimus offer an opportunity for comparative analysis in an eco-evo-devo framework.
\end{abstract}

Keywords: hybridization; introgression; island endemism; Lotus; nomenclature; North America; plant taxonomy; species; subspecies; variety

\section{Introduction}

North American species formerly classified in Lotus [1-3] have a center of diversity in California. According to Brouillet [4-6], they are currently placed in two genera, Acmispon Raf. and Hosackia Dougl. ex Benth., though some earlier accounts placed all native North American species in Hosackia (e.g., [7]) or instead recognized as many as four genera of Loteae in North America (e.g., [8]). Species currently remaining classified in Lotus have a center of diversity in the Mediterranean region, which is also the area of primary taxonomic diversity of the entire tribe Loteae.

Many species of Loteae show considerable morphological variation. Thus, numerous interspecific taxa and "microspecies" have been described during the past two centuries from various countries. Both European and American botanists once used a diversity of taxonomic ranks to name infraspecific taxa. However, since the second half of 20th century, two contrasting traditions became clear [9]. Taxonomic and floristic accounts of European and Mediterranean plants commonly make an emphasis on recognizing subspecies. In contrast, accounts of North American Loteae recognize all infraspecific taxa as varieties. In addition, the proportion of species with fully accepted (numbered) infraspecific taxa differs between the two regions. In California, Brouillet [5,6] accepted in total 30 species of Loteae (in Acmispon and Hosackia), with as many as 14 species possessing recognized varieties. A comparison can be made to the Iberian Peninsula, where members of Loteae are most 
diverse in Europe. Out of 78 species of Loteae accepted in Flora Iberica, only seven have recognized subspecies [10].

The discussion on taxonomic ranks of subspecies and variety has a long history. The idea of geographically defined subspecies developed in the framework of Ernst Mayr's biological species concept is most consistently applied in ornithology [11-15], also using molecular methods $[16,17]$. This approach was, however, extensively criticized by entomologists Wilson and Brown [18]. They concluded that as the analyses of geographical variation become more complete, formal recognition of infraspecific taxa (subspecies) will be revealed as inefficient and superfluous for reference purposes. In botany, Clausen [19] advocated the use of geographically defined subspecies in the same way as in ornithology. Fosberg [20] suggested more pluralism in the use of taxon ranks to accommodate infraspecific variation. Kapadia [21] preferred recognizing varieties as basic infraspecific taxa that, when necessary, can be grouped into subspecies. There is an approach of recognizing local plant races at the rank of species rather than subspecies [22]. An important factor is that modes of infraspecific variation are more diverse in angiosperms than in birds because of widespread polyploidy, reticulate evolution, and diverse patterns of plant reproduction (e.g., $[23,24])$.

Of course, it is nearly impossible to find any general solution to the problem of inconsistent approaches in recognizing infraspecific taxa (see [9]), but we believe that attempts should be made. This is important because general conclusions inferred from meta-analyses of big data may be biased by different taxonomic practices adopted in various countries. For example, does the apparently more frequent occurrence of species with infraspecific differentiation reflect a less complete process of speciation in North American Loteae? It is reasonable to use the rank of subspecies for geographically defined infraspecific units with localized zones of intergradation [25-27]. If there is a need of recognizing any infraspecific taxa that do not meet this criterion, these can be accepted as varieties or forms. As suggested by Brummitt [25], members of a variety tend to occur in uniform populations, but different varieties of a species would not show a discrete geographical distribution. A form would be a conspicuous morphological variant occurring with other plants in mixed populations [25]. As further noticed by Brummitt [25], real patterns of plant diversity are not always that simple and practical use of definitions is often difficult. For example, what is a population, especially if a plant is relatively rare? We believe that in most cases taxonomic recognition should not be focused on exhaustive uncovering of all varieties and forms. Taxa of these ranks can be included in taxonomic accounts when their members are of practical use, when there is a need to emphasize distinctive character states (e.g., flower color or form) or when they are considered remarkable for any other reason.

The primary interest in recognizing subspecies rather than varieties can be defended by the presence of a much more substantive theoretical concept for subspecies rather than for varieties and forms. Such subspecies may turn to be at least partially compatible across continents and taxonomic groups.

We are far from suggesting that all Californian varieties should be merely transferred into the rank of subspecies. Apparently, the practice of recognizing infraspecific taxa should be revised in Europe and the Mediterranean region in the same way as in North America. Some subspecies currently accepted in the Old World do not meet the geographical criterion, for example, in the polytypic species concept of Anthyllis vulneraria [28] many subspecies are sympatric.

In light of these ideas, here we discuss taxa traditionally included in or associated with Acmispon glaber (Vogel) Brouillet (=Syrmatium glabrum Vogel).

\section{Materials and Methods}

The work is based on analyses of herbarium collections (physical or available as digital images) deposited in CAS, GH, K, US, NY. Type material from other collections 
was examined when necessary. Acronyms of Herbaria are indicated according to Index herbarium [29].

\section{Results}

Those taxonomists of the 20th century who interpreted all North American Loteae as members of the genus Lotus classified the species currently known as Acmispon glaber under the name Lotus scoparius (Torr. \& A.Gray) Ottley (=Hosackia scoparia Torr. \& A.Gray), because there is an earlier Old World name Lotus glaber Miller. Types of Syrmatium glabrum and Hosackia scoparia were collected at the coast of mainland California. There is no question that they belong to the same taxon. This plant is common throughout the coastal ranges of California from Humboldt County into northern Baja California, and in a thin belt along the foothills of the Sierra Nevada [30]. A closely related taxon occurs in interior southern California and in Baja California. It was first described as Lotus scoparius var. brevialatus Ottley and taxonomic accounts highlight its differences from L. scoparius var. scoparius in characteristically short wings of the corolla, which are shorter than the keel $[1,3]$. Detailed studies of Steppan [30] strongly supported the view that the coastal taxon and the inland taxon are two subspecies rather than two varieties [7,31]. They fit the conceptual criteria of geographically-defined subspecies with a narrow zone of introgression. As nicely demonstrated by Steppan [30], morphological differences between the two subspecies of Acmispon glaber (= Lotus scoparius) include nearly every flower part in both form and size, indicating the effects of multiple genes. These differences are maintained in plants grown from seeds in common garden experiments [32,33]. The hybrids form a morphologically well-defined group and no clear evidence of back-crosses was found, though this question was not analyzed in detail $[30,33]$. The ranges of the two subspecies are latitudinally elongated and the length of the contact zone is over $400 \mathrm{~km}$ while the width of the transition zone is only 1 to $10 \mathrm{~km}$. The boundary between the ranges nicely fits climatic and biogeographical data [30]. In accordance with environmental conditions, the range of the subspecies with short wings extends much more to the south than that of the type subspecies and reaches the Pacific coast in the southern part of Baja California and northern part of Baja California Sur near Cedros Island. We see no reason to follow the concept of recognizing the two taxa of $A$. glaber merely as varieties. As no valid combination is available for the subspecies with short wings in the genus Acmispon, we propose it below.

Cedros Island is located $22 \mathrm{~km}$ from the closest coast of Baja California Sur. Acmispon nudatus (Greene) Brouillet (=Lotus nudatus (Greene) Greene) is endemic to Cedros Island. In flower morphology, it strongly resembles the mainland A. glaber subsp. brevialatus, and this flower morphotype is not recorded in any other member of the genus. The Cedros Island endemic has one- or two-flowered umbels and short flowering branches, which are curved and not broomlike whereas the mainland taxon has one- to six-flowered umbels, and longer flowering branches, which are erect or ascending and broomlike [34]. To our knowledge, heritability of the differences in habit was not tested experimentally. The habit of $A$. glaber is not uniform. A prostrate form is known in A. glaber subsp. glaber. Therefore, the main difference is the number of flowers per umbel. The ranges of variation in flower number per umbel are completely overlapping, but in A. glaber subsp. brevialatus (and A. glaber subsp. glaber), every plant normally has at least some umbels with more than three flowers. Analysis of herbarium collections revealed sporadic occurrence of three-flowered umbels in A. nudatus. Though detailed field observations and molecular data are necessary, it seems that the boundary between $A$. nudatus and A. glaber subsp. brevialatus is not abrupt. There is a specimen where most umbels have three flowers, so is morphologically intermediate between them (about 13 miles N by road from San Luis Gonzaga, 24 Mar 1970, Powell \& Turner 1755-US 2578071A!). In our view, it is reasonable to accept the Cedros Island taxon as yet another subspecies of $A$. glaber. It seems that $A$. glaber subsp. brevialatus is even closer to A. glaber subsp. nudatus than to A. glaber subsp. glaber and one of us earlier suggested that the former two taxa should be combined [35]. 
Acmispon dendroideus (Greene) Brouillet (=Lotus dendroideus (Greene) Greene) is currently viewed as a species with three varieties occurring on the California Channel Islands [3,5]. These varieties were first described at the rank of species [36-38], then reconsidered as varieties [1] or sometimes subspecies [39] of Lotus scoparius. Isely [40] created the current species concept by classifying mainland Californian plants under $L$. scoparius and their Channel Islands relatives as distinct species L. dendroideus with three varieties. Among other characters and tendencies, the Channel Islands plants differ from the mainland plants in (shortly) pedunculate rather than sessile umbels. This character is important because it also distinguishes Acmispon glaber from two other mainland species. Channel Island populations of $A$. dendroideus were recently in detail investigated using molecular methods and approaches of phylogeography and island biogeography [41-43]. These studies revealed that Channel Island specimens of $A$. dendroideus form two wellsupported clades.

The first clade includes samples of $A$. dendroideus var. traskiae (Eastw. ex Abrams) Brouillet that is endemic to the southernmost of the Channel Islands, San Clemente. Molecular data suggest that it can be recognized as a separate species [42]. Morphology strongly supports this idea. Already the ovary with as many as four to six ovules and the long fruit exceeding $2 \mathrm{~cm}$ [3] distinguishes this species from all other Channel Island members of Acmispon as well as from the mainland A. glaber. There is no published name in Acmispon for this species and we propose a new combination below.

The second clade includes samples of two traditionally recognized varieties, A. dendroideus var. dendroideus from the islands Santa Catalina, Anacapa, Santa Cruz, and Santa Rosa and A. dendroideus var. veatchii (Greene) Brouillet from the northwesternmost island San Miguel. It was concluded that genetic data do not support distinguishing $A$. dendroideus var. veatchii from $A$. dendroideus var. dendroideus [42]. Morphologically, A. dendroideus var. veatchii was distinguished by sericeous rather than more sparse indumentum, but not all collections can be easily identified using this criterion. Therefore, recognizing only one taxon is reasonable. The name Hosackia veatchii Greene [36] was proposed a year earlier than Syrmatium dendroideum Greene [37] and thus has a priority. Therefore, we propose a new combination, Acmispon veatchii. An intriguing problem is that the type specimen of Hosackia veatchii comes from Mexico. The protologue [36] states that the species is described using the single collection made by Veatch in Elide, Lower California near Cedros Island. Elide is a small island c. $4 \mathrm{~km}$ WNW of Santa Rosalíta, Baja California. Iseley $[3,40]$ studied a Veatch specimen in UC and regard it as "fragments of isotype". There is another specimen in CAS that appears to be the main collection and has an original label. Examination of its image convinced us in the conclusion of Isely $[3,40]$ that the plant has no differences from those occurring in San Miguel Island. Ironically, of all the Channel Islands, San Miguel is furthest from Baja California. We did not see other collections of this species from Mexico and reports in the literature are controversial [34,44]. Isely [40:467] suggested that the Baja California occurrence (the type collection of $H$. veatchii) is probably secondary, since the genesis of the complex seems to have taken place on the California coastal islands. One may suggest a mixture in labels because what appears to be the original label in the CAS specimen has no taxon name. Further progress in the taxonomy of Acmispon will greatly benefit from integrating molecular and morphological data on the island and mainland accessions from both the United States and Mexico.

Formal nomenclatural treatment for Acmispon glaber is provided below.

Acmispon glaber (Vogel) Brouillet 2008, J. Bot. Res. Inst. Texas 2: 389. $\equiv$ Syrmatium glabrum Vogel 1836, Linnaea, 10: 591. - Lectotype (designated by Sokoloff 1999, Taxon 48: 58): Calif[ornia], A. v. Cham[isso]s.n. (LE 01072410!).

= Lotus scoparius (Torr. \& A.Gray) Ottley 1923, Univ. Calif. Publ. Bot. 10: 227. 三 Hosackia scoparia Torr. \& A.Gray 1838, Fl. N. Amer. 1: 325. - Syntypes: St. Diego, N. Calif[ornia], Nuttall s.n. (GH 00061034!, only left-hand specimen; NY 00015478!; BM 000901295, image seen;). The specimen from Gray Herbarium (GH) is a small fragment 
of a larger specimen. We avoid selecting lectotype before an extensive search of all potential syntypes.

A. glaber subsp. brevialatus (Ottley) Akulova-Barlow \& D.D. Sokoloff, comb. et stat. nov.-Basionym: Lotus scoparius var. brevialatus Ottley 1923, Univ. Calif. Publ. Bot. 10: 229. $\equiv$ Hosackia glabra subsp. brevialata (Ottley) Abrams 1944, Ill. Fl. Pacific States 2: 552. 三Lotus scoparius subsp. brevialatus (Ottley) Munz 1974, Fl. S. Calif.: 450. $\equiv$ Acmispon glaber var. brevialatus (Ottley) Brouillet 2008, J. Bot. Res. Inst. Texas 2: 390.-Lectotype (designated here): California, Los Angeles Co.; San Gabriel Mts., Little Tujunga Wash, 03.05.1920, A.M. Ottley 589 (JEPS 19470, image seen; isolectotype NY 00015752!). In the protologue, Ottley [1] did not indicate the location of the type specimen. The specimen in JEPS is here selected as lectotype, because the study of Ottley was conducted under the supervision of W.L. Jepson.

A. glaber subsp. nudatus (Greene) Akulova-Barlow \& D.D. Sokoloff, comb. nov.Basionym: Syrmatium nudatum Greene 1888, Pittonia 1: 173. 三 Lotus nudatus (Greene) Greene, 1890, Pittonia 2: 148. 三 Hosackia nudata (Greene) Vasey \& Rose, 1890, Contr. U.S. Natl. Herb. 1: 14. $\equiv$ Acmispon nudatus (Greene) Brouillet 2008, J. Bot. Res. Inst. Texas 2: 391.-Lectotype (designated here): Lower California, Cedros Island, 01.05.1885, E.L. Greene s.n. (NDG 25728, image seen). We did not find duplicate material for this name so although there is a possibility this is the holotype, we cannot be sure that no other material exists or was available at the time and, therefore, we choose to designate the specimen as lectotype.

A. traskiae (Eastw. ex Abrams) D.D. Sokoloff \& Akulova-Barlow, comb. nov.Basionym: Syrmatium traskiae Eastw. ex Abrams 1917, Fl. Los Angeles: 201. 三 Lotus scoparius var. traskiae (Eastw. ex Abrams) Ottley 1923, Univ. Calif. Publ. Bot. 10: 229. $\equiv$ Lotus scoparius subsp. traskiae (Eastw. ex Abrams) P.H. Raven 1963, Aliso 5: 326. $\equiv$ Lotus dendroideus var. traskiae (Eastw. ex Abrams) Isely 1978, Brittonia 30: 467. $\equiv$ Acmispon dendroideus var. traskiae (Eastw. ex Abrams) Brouillet 2008, J. Bot. Res. Inst. Texas 2: 389.-Lectotype (designated here): San Clemente Island, Cal[ifornia], Mosquito Har[bor], Jun. 1903, B Trask 287 (US 469581, image seen; isolectotype NY 15486, image seen).

A. veatchii (Greene) Govaerts, comb. nov.-Basionym: Hosackia veatchii Greene 1885, Bull. Calif. Acad. Sci. 1(3): 83. ESyrmatium veatchii (Greene) Greene 1886, Bull. Calif. Acad. Sci. 2: 148. $\equiv$ Lotus veatchii (Greene) Greene 1890, Pittonia 2: $148 . \equiv$ Lotus scoparius var. veatchii Ottley 1923, Univ. Calif. Publ. Bot. 10: 228. 三 Lotus dendroideus var. veatchii (Greene) Isely 1978, Brittonia 30: 467. 三 Acmispon dendroideus var. veatchii (Greene) Brouillet 2008, J. Bot. Res. Inst. Texas 2: 389.-Lectotype (designated here): "Main Land near Elide opposite Cerras Island Lower Cal., Dr. [J.A.] Veatch" (CAS 0002992, image seen; isolectotype UC, not seen).

= Syrmatium dendroideum Greene 1886, Bull. Calif. Acad. Sci. 2: 146. $\equiv$ Lotus dendroideus (Greene) Greene 1890, Pittonia 2: 148. 三Lotus scoparius var. dendroideus (Greene) Ottley 1923, Univ. Calif. Publ. Bot. 10: 228. 三 Hosackia dendroidea (Greene) Abrams 1944, Ill. Fl. Pacific States 2: 552. 三 Acmispon dendroideus (Greene) Brouillet 2008, J. Bot. Res. Inst. Texas 2: 389.-Lectotype (designated here): Island of Santa Cruz, Coast of California, Jul. \& Aug. 1886, E.L. Greene s.n. (CAS 0005448, image seen; isolectotypes CAS 0005447, MO 256371, 256372, NY 00033780, PH 00029821, 00029822, US 01107563, images seen). In the protologue, Greene [37] stated that he studied material from the highest parts of Santa Cruz Island, but did not cite any herbarium specimen. We found no original material other than cited above.

= Syrmatium patens Greene 1886, Bull. Calif. Acad. Sci. 2: 147.-Lectotype (designated here): California, Island of San Miguel, Sep. 1886, E.L. Greene s.n. (CAS 0005452, image seen). There are duplicates in NY and PH. In the protologue, Greene [37] stated that the plant occurs in the Island of San Miguel, in the Cañon del Mar, but is more abundant on the summit of the islet known as Gull Island, a mile or more off the shore. Greene [37] cited no herbarium specimen. We found no original material other than cited above. 


\section{Discussion}

Infraspecific taxa currently recognized in North American Loteae require further detailed taxonomic studies. We hope that the present study provides an example of an appropriate use of the rank of subspecies in a North American member of the tribe. Apparently, subspecies rather than varieties should be recognized in a number of other species of North American Loteae (and other plant groups). An attempt at harmonization of taxonomic concepts across countries is the only way to ensure that global taxonomic databases deal with real plant diversity rather than catalog records.

Further progress in understanding the evolution of Acmispon will benefit from a detailed phylogenetic study covering all mainland and island members of the group across their entire ranges. In our view, Acmispon provides an opportunity for research in the field of eco-evo-devo (e.g., [45]). As highlighted by Steppan [30]), there is another species, currently known as Acmispon maritimus (Nutt.) D.D.Sokoloff, which shares with A. glaber the occurrence of an inland subspecies characterized by a keel longer than the wings (Acmispon maritimus subsp. brevivexillus (Ottley) D.D. Sokoloff, stat. nov.-Basionym: Lotus salsuginosus var. brevivexillus Ottley 1923, Univ. Calif. Publ. Bot. 10: 217. $\equiv$ Acmispon maritimus var. brevivexillus (Ottley) Brouillet 2008, J. Bot. Res. Inst. Texas 2: 391 三Lotus humilis Greene 1890, Pittonia 2: 140. Type: Lower California, San Bartolomé Bay, Mar. 1889, Pond; isotype US23908, barcode 02307786, image seen; holotype NDG?). Steppan [30] noticed that similar distribution patterns of the short-winged subspecies in these two species suggests convergent adaptation to an inland environment or pollinators. The ranges of the two long-keeled subspecies are similar, but not identical, as the eastern part of the range of A. maritimus subsp. brevivexillus extends into the deserts [30]. It will be interesting to learn whether the genetic bases of development of flowers with long keel (more precisely, with short wings and standard) are the same in the two inland subspecies. The functional significance of the differences in relative petal length could be inferred using field experiments. Detailed study of the pollination biology of A. glaber subsp. glaber revealed that the changes in the standard shape and petal color induced by pollination are of adaptive significance [46]. Apparently, the occurrence of a much shorter standard must be related to differences in pollination biology (a shift to self-pollination?).

A general question that remains to be resolved is whether the apparently more frequent occurrence of species with infraspecific differentiation reflects a less complete process of (more recent?) speciation in North American Loteae than in the Mediterranean region. Alternatively, the apparent difference may be mainly caused by the differences in taxonomic approaches adopted by botanists at the two sides of the Atlantic. Resolving the question will be facilitated by a more consistent use of criteria for recognizing infraspecific taxa, direct comparisons of levels of infraspecific variation using statistical approaches, dating more detailed molecular phylogenetic trees (e.g., $[47,48]$ ), and comparing ratios of species with recognized subspecies or varieties in different geographical regions across large data sets that include various taxonomic groups. The recently published worldwide checklist of legumes [49] provides an opportunity of making such comparisons.

\section{Conclusions}

Harmonization of taxonomic concepts across countries is essential for a more accurate representation of data in global biodiversity databases. Some varieties currently recognized in North American Loteae should be better interpreted as subspecies. This idea requires further detailed investigations at both morphological and molecular levels. Inland subspecies of Acmispon maritimus and A. glaber offer an opportunity for comparative analysis in the framework of eco-evo-devo.

Author Contributions: Conceptualization, D.D.S., Z.V.A.-B. and R.G.; analyses of collections, D.D.S. and Z.V.A.-B.; writing-original draft preparation, D.D.S.; writing-review and editing, Z.V.A.-B. and R.G. All authors have read and agreed to the published version of the manuscript. 
Funding: The research of D.D.S. was carried out in accordance with Government order for the Lomonosov Moscow State University (project 121032500084-6).

Data Availability Statement: Not applicable.

Acknowledgments: We are grateful to Galina Degtjareva, Tatiana Kramina, and Tahir Samigullin for discussion on the phylogeny of Loteae, to Larisa Orlova for help with specimens located in LE, and to four anonymous reviewers for helpful comments and suggestions.

Conflicts of Interest: The authors declare no conflict of interest.

\section{References}

1. Ottley, A.M. A revision of the Californian species of Lotus. Univ. Calif. Publ. Bot. 1923, 10, 189-305.

2. Ottley, A.M. The American Loti with special consideration of a proposed new section. Simpeteria Brittonia 1944, 5, 81-123. [CrossRef]

3. Isely, D. Leguminosae of the United States. III. Subfamily Papilionoieae: Tribes Sophoreae, Podalyrieae, Loteae. Mem. N. Y. Bot. Gard. 1981, 25, 1-264.

4. Brouillet, L. The taxonomy of North American loti (Fabaceae: Loteae): New names in Acmispon and Hosackia. J. Bot. Res. Inst. Texas 2008, 2, 387-394.

5. Acmispon, in Jepson Flora Project; Jepson eFlora, Ed.; The Jepson Herbarium, University of California: Berkeley, CA, USA, 2012. Available online: https:/ / ucjeps.berkeley.edu/eflora/eflora_display.php?tid=67950 (accessed on 10 May 2021).

6. Hosackia, in Jepson Flora Project; Jepson eFlora, Ed.; The Jepson Herbarium, University of California: Berkeley, CA, USA, 2012. Available online: https:/ / ucjeps.berkeley.edu/eflora/eflora_display.php?tid=68646 (accessed on 10 May 2021).

7. Abrams, L.R. Illustrated Flora of the Pacific States; Stanford University Press: Stanford, CA, USA, $1944 ;$ Volume 2.

8. Sokoloff, D.D.; Degtjareva, G.V.; Endress, P.K.; Remizowa, M.V.; Samigullin, T.H.; Valiejo-Roman, C.M. Inflorescence and early flower development in Loteae (Leguminosae) in a phylogenetic and taxonomic context. Int. J. Plant Sci. 2007, 168, 801-833. [CrossRef]

9. Hamilton, C.W.; Reichard, S.H. Current practice in the use of subspecies, variety, and forma in the classification of wild. Taxon 1992, 41, 485-498. [CrossRef]

10. Talavera, S.; Castroviejo, S.; Herrero, A.; Romero Zarco, C.; Salgueiro, F.J.; Velayos, M. (Eds.) Flora Iberica: Leguminosae; Real Jardín Botánico: Madrid, Spain, 2000; Volume 7, 1119p.

11. Mayr, E. Speciation phenomena in birds. Am. Nat. 1940, 74, 249-278. [CrossRef]

12. Mayr, E. Systematics and the Origin of Species, from the Viewpoint of a Zoologist; Harvard University Press: Cambridge, MA, USA, 1942; 334p.

13. Mayr, E. Of what use are subspecies? Auk 1982, 99, 593-595.

14. O'Neill, J.P. The subspecies concept in the 1980's. Auk 1982, 99, 609-612.

15. Mallet, J. Subspecies, semispecies, superspecies. In Encyclopedia of Biodiversity; Levin, S.A., Ed.; Elsevier: Amsterdam, The Netherlands, 2007; pp. 1-5.

16. Phillimore, A.B.; Owens, I.P.F. Are subspecies useful in evolutionary and conservation biology? Proc. R. Soc. B 2006, 273, 1049-1053. [CrossRef] [PubMed]

17. Patten, M.A. Subspecies and the philosophy of science. Auk 2015, 132, 481-485. [CrossRef]

18. Wilson, E.O.; Brown, W.L., Jr. The subspecies concept and its taxonomic application. Syst. Zool. 1953, 2, 97-111. [CrossRef]

19. Clausen, R.T. On the use of the terms "subspecies" and "variety". Rhodora 1941, 43, 157-167.

20. Fosberg, F.R. Subspecies and variety. Rhodora 1942, 44, 153-157.

21. Kapadia, Z.J. Varietas and subspecies, a suggestion towards greater uniformity. Taxon 1963, 12, 257-259. [CrossRef]

22. Komarov, V.L. Introduction. In Flora SSSR; Komarov, V.L., Ed.; Izdatelstvo Akademii Nauk SSSR: Leningrad, USSR, 1934; pp. 1-12.

23. Grant, W. Plant Speciation; Columbia University Press: New York, NY, USA, 1981; 563p.

24. Soltis, D.E.; Visger, C.J.; Soltis, P.S. The polyploidy revolution then and now: Stebbins revisited. Am. J. Bot. 2014, 101, 1057-1078. [CrossRef] [PubMed]

25. Brummitt, R.K. Species, subspecies, variety or form-An old problem revisited in tropical African Protea. Mitteilungen aus dem Institut für Allgemeine Botanik in Hamburg 1990, 23b, 677-682.

26. Wood, J.R.I.; Williams, B.R.M.; Mitchell, T.C.; Carine, M.A.; Harris, D.J.; Scotland, R.W. A foundation monograph of Convolvulus (Convolvulaceae). PhytoKeys 2015, 51, 19.

27. Govaerts, R. World Checklist of Selected Plant Families (WCSP); Royal Botanic Gardens: Kew, Richmond, UK, 2021; Available online: https:/ / wcsp.science.kew.org/about.do\#names (accessed on 10 June 2021).

28. Cullen, J. The Anthyllis vulneraria complex: A résumé. Not. Roy. Bot. Gard. Edinb. 1976, 35, 3-38.

29. Thiers, B. Index Herbariorum: A Global Directory of Public Herbaria and Associated Staff. Continuously Updated. Virtual Herbarium, New York Botanical Garden: Bronx, NY, USA, 2018. Available online: http://sweetgum.nybg.org/ih/ (accessed on 10 June 2021). 
30. Steppan, S.J. Geographic distribution of flower morphological traits in subspecies of Lotus scoparius. J. Biogeogr. 1991, 18, 321-331. [CrossRef]

31. Munz, P.A. A Flora of Southern California; University of California Press: Berkeley, NJ, USA, 1974; 1086p.

32. Montalvo, A.M.; Ellstrand, N.C. Transplantation of the subshrub Lotus scoparius: Testing the home site advantage hypothesis. Conserv. Biol. 2000, 14, 1034-1045. [CrossRef]

33. Montalvo, A.M.; Ellstrand, N.C. Non-local transplantation and outbreeding depression in the subshrub Lotus scoparius (Fabaceae). Am. J. Bot. 2001, 88, 258-259. [CrossRef]

34. Wiggins, I.L. Flora of Baja California; Stanford University Press: Stanford, CA, USA, 1980; 1025p.

35. Sokoloff, D.D. Morphology and Classification of the Tribe Loteae DC. of the Family Leguminosae. Ph.D. Thesis, Moscow State University, Moscow, Russia, 2003; pp. 1-704.

36. Greene, E.L. Studies in the botany of California and parts adjacent, I. Bull. Calif. Acad. Sci. 1885, 1, 66-127.

37. Greene, E.L. Studies in the botany of California and parts adjacent, V. Bull. Calif. Acad. Sci. 1886, 2, 125-149.

38. Abrams, L.R. Flora of Los Angeles and Vicinity; Stanford University Press: Stanford, CA, USA, 1917; 432p.

39. Raven, P.H. A flora of San Clemente Island, California. Aliso 1963, 5, 289-347. [CrossRef]

40. Iseley, D. New varieties and combinations in Lotus, Baptisia, Thermopsis and Sophora (Leguminosae). Brittonia 1978, 30, 466-472. [CrossRef]

41. McGlaughlin, M.E.; Wallace, L.E.; Wheeler, G.L.; Bresowar, G.; Riley, L.; Britten, N.R.; Helenurm, K. Do the island biogeography predictions of MacArthur and Wilson hold when examining genetic diversity on the near mainland California Channel Islands? Examples from endemic Acmispon (Fabaceae). Bot. J. Linn. Soc. 2014, 174, 289-304. [CrossRef]

42. McGlaughlin, M.E.; Riley, L.; Helenurm, K.; Wallace, L.E. Does Channel Island Acmispon (Fabaceae) form cohesive evolutionary groups? West. N. Am. Nat. 2018, 78, 739-757. [CrossRef]

43. Wallace, L.E.; Wheeler, G.L.; McGlaughlin, M.E.; Bresowar, G.; Helenurm, K. Phylogeography and genetic structure of endemic Acmispon argophyllus and A. dendroideus (Fabaceae) across the California Channel Islands. Am. J. Bot. 2017, 104, 743-756. [CrossRef] [PubMed]

44. Vanderplank, S.; Rebman, J.; Ezcurra, E. Revised and updated vascular plant checklists for the Baja California Northern Pacific Islands. West. N. Am. Nat. 2018, 78, 674-698. [CrossRef]

45. Abouheif, E.; Favé, M.J.; Ibarrarán-Viniegra, A.S.; Lesoway, M.P.; Rafiqi, A.M.; Rajakumar, R. Eco-Evo-Devo: The time has come. In Ecological Genomics: Ecology and the Evolution of Genes and Genomes; Landry, C.R., Aubin-Horth, N., Eds.; Springer: Cham, Switzerland, 2014; pp. 107-125.

46. Jones, C.E.; Cruzan, M.B. Floral morphological changes and reproductive success in deer weed (Lotus scoparius, Fabaceae). Am. J. Bot. 1999, 86, 273-277. [CrossRef] [PubMed]

47. Jaén-Molina, R.; Marrero-Rodríguez, Á.; Caujapé-Castells, J.; Ojeda, D.I. Molecular phylogenetics of Lotus (Leguminosae) with emphasis in the tempo and patterns of colonization in the Macaronesian region. Mol. Phylogenet. Evol. 2021, 154, 106970. [CrossRef] [PubMed]

48. Kramina, T.; Lysova, M.; Samigullin, T.; Schanzer, I.; Özbek, M.; Sokoloff, D. Phylogenetic placement and phylogeography of large-flowered Lotus species (Leguminosae) formerly classified in Dorycnium: Evidence of pre-pleistocene differentiation of western and eastern intraspecific groups. Plants 2021, 10, 260. [CrossRef] [PubMed]

49. Legume Phylogeny Working Group (LPWG); Andrella, G.C.; Atahuachi Burgos, M.; Bagnatori Sartori, Â.L.; Balan, A.; Bandyopadhyay, S.; Barrett, R.L.; Barbosa Pinto, R.; Brullo, S.; Boatwright, J.S.; et al. The World Checklist of Vascular Plants (WCVP): Fabaceae; vers. June 2021; Govaerts, R., Ed.; Royal Botanic Gardens, Kew: London, UK, 2021. Available online: http:/ / sftp.kew.org/pub/data_collaborations/Fabaceae/DwCA/ (accessed on 20 July 2021). 